\title{
EDITORIAL
}

\section{Influenza humana: cuando el alarmismo es peor que la enfermedad*}

La aparición de personas contagiadas con la influenza humana en México y la detección de casos también en otros países -entre ellos Chile-, generó una respuesta inmediata en los sistemas de salud no sólo de las zonas geográficas afectadas, sino de todo el mundo. La experiencia vivida hace unos años con el SARS y más recientemente con la gripe aviar, es una muestra de que la globalización plantea desafíos que van mucho más allá de los acuerdos comerciales y los intercambios culturales.

Chile no ha estado ajeno a los acontecimientos y las autoridades de salud han adoptado medidas similares a las de otros países, en concordancia con las directrices del Reglamento Sanitario Internacional (RSI), iniciativa que proporciona el marco de acción para evitar la propagación de enfermedades de origen infeccioso. Tomando en cuenta el carácter cambiante e impredecible de la diseminación internacional de estas patologías, el RSI fue mejorado el año 2005 con el fin de hacer frente a una probable pandemia de influenza H5N1. Tras ello, la propia Organización Panamericana de la Salud reconoció que el fortalecimiento de la capacidad de responder a casos humanos de esta enfermedad y la amenaza pandémica correspondiente, mejorarían también la capacidad de hacer frente a muchas otras enfermedades infecciosas emergentes y reemergentes, aumentando la seguridad de la salud pública mundial.

Por otro lado, nuestro país es reconocido por la alta educación en salud de su población, la que quedó demostrada, por ejemplo, en la campaña contra el cólera a comienzos de la década de los '90. En esa ocasión, la ciudadanía contó con la información necesaria y reaccionó en forma madura y responsable, siguiendo las recomendaciones de las autoridades sanitarias y adoptando las conductas de prevención. Es más, éstas se convirtieron en un cambio de hábitos y lograron mantenerse después de que el brote fue totalmente controlado, mejorando ostensiblemente las condiciones de salud y calidad de vida de la gente. Hay, entonces, razones para ser optimistas y pensar que el virus A H1N1 nos dejará mejor preparados para el próximo invierno.

La influenza humana es una enfermedad infecciosa para la cual la población no tiene inmunidad; por lo tanto, cuando el agente patógeno entra en algún lugar y/o ambiente donde no ha existido previamente, lo esperable es que se produzcan casos. Su llegada a Chile era sólo cuestión de tiempo, ya que es imposible detectar a las personas durante el período preclínico (asintomático), en el cual no hay manifestaciones de signos ni de síntomas. Por otra parte, los virus son microorganismos muy "exitosos", si es que los podemos llamar así, en términos de apoderarse de la maquinaria celular y hacer que la célula trabaje para ellos. Muchos tienen la capacidad de mutar constantemente, por lo que la cepa de un año a otro puede variar en forma significativa, motivo por el cual las vacunas cambian regularmente.

Teniendo estos antecedentes en cuenta, la alarma pública a la que hoy nos enfrentamos se debe poner en su contexto. Afortunadamente la letalidad es baja, lo que significa que el porcentaje de muertes que se pudiera producir es incluso inferior a las esperadas para nuestra habitual gripe estacional. Por otra parte, ya se sabe cuáles son los grupos de mayor riesgo y cuáles son las medidas básicas para disminuir las probabilidades de contagio. Lo que genera mayor preocupación es la rápida propagación de la enfermedad, la que se debe -básicamente- a que la población no tiene inmunidad desarrollada y, por lo tanto, puede enfermar mucha gente, como de hecho ha ocurrido.

Se ha hablado de posibles nuevas mutaciones del virus, lo que puede ocurrir también con otros. Este tema siempre está presente, ya que es un mecanismo de adaptación a las condiciones del

Parte de los contenidos de esta editorial fueron publicados en el diario La Tercera. 
medio. Por esto, si las personas consumen antigripales que no han sido prescritos por un médico, con la idea de que así van a evitar enfermarse, están haciendo un flaco favor a la población en general, ya que sólo van a generar resistencia al medicamento y, por lo tanto, cuando realmente se necesite, éste no tendrá efecto. Los antigripales sólo deben ser recetados por el facultativo y usados como prevención en aquellos individuos que se sabe que estuvieron en contacto con una persona con diagnóstico confirmado.

No hay cómo predecir si una persona resultará contagiada, pero la única forma de cortar la cadena de transmisión es siguiendo al pie de la letra las instrucciones de las autoridades de salud. En este sentido, la decisión de algunos colegios de suspender las clases apunta precisamente a interrumpir la cadena de contacto y evitar que la enfermedad se extienda.

Debemos estar preparados y evitar entrar en un alarmismo peor que la enfermedad. Lo más probable es que se sigan produciendo casos, al menos durante los meses más críticos del invierno. Si pensamos en términos de riesgo, un brote epidémico tiene efectos mediáticos muy fuertes, ya que habitualmente se produce un gran número de casos en un período muy corto de tiempo. Sin embargo, en Chile y en el mundo tenemos epidemias que causan menos pánico -como la obesidad, los accidentes de tránsito o el consumo de tabaco-, pero que provocan gravísimos efectos en la salud de las personas en términos de morbilidad y mortalidad y que tienen, además, la particularidad de ser evitables.

Dres. Dante Cáceres y Beatriz Marincovich

Escuela de Salud Pública

Facultad de Medicina

Universidad de Chile 